Trends in Horticulture (2018) Volume 1

doi: $10.24294 /$ th.v1i2.623

\title{
An Overview of Sweet Cherry Fruit Cultivation in Turkey Deniz Erogul
}

Ege University, Faculty of Agriculture, Department of Horticulture, Bornova, 35100 Izmir, Turkey

\begin{abstract}
Sweet cherry is a type of fruit that is high on demand in exports for table consumption. Turkey is a gene centre for sweet cherry fruit. Fruits are produced over an extended period because of the ecological richness and large cultivation area, which allows Turkey to remain as the leader of sweet cherry production in the world. The variety, '0900 Ziraat', also known as the Turkish sweet cherry fruit, has the highest production volume. Mazzard and Mahaleb are the commonly used rootstocks for sweet cherry cultivation; and Mazzard is used more frequently than Mahaleb. Clonal rootstocks are used to maintain cultivation in new orchards. The present study provides a detailed information on the current status of sweet cherry fruit cultivation in Turkey as well as its cultivation practices and exports. It is targeted that modern irrigation techniques, good agricultural practices, and increased cultivation areas are established to maintain Turkey's position as the leader in global sweet cherry production and exports.

Keywords: Sweet Cherry; Rootstock; Sweet Cherry Exportation; Turkey
\end{abstract}

\section{Introduction}

Turkey is a unique country in the world where several types of fruit can be cultivated under good conditions and with superior quality owing to vast, fertile agricultural fields suitable for production and with the help of the ecological diversity in various regions. The agricultural fields in Turkey span approximately 24 million hectares; and $13.5 \%$ of this area is used for fruit cultivation. Due to its high potential for fruit cultivation, in 2017, 20 million 809 thousand tons of fruit were cultivated in Turkey and fruit cultivation volume increased by $9.7 \%$ compared with the previous year (TUIK, 2017).

\section{Sweet cherry production}

Currently, Turkey is the top sweet cherry fruit producer in the world with a cultivation volume of 599.650 tons. Turkey is followed by the USA (288.480 t) and Iran (220.393t) in sweet cherry production (FAO, 2017). In Turkey, sweet cherry fruit is cultivated in different regions; and the cultivation period is prolonged because of ecological advantages. Therefore, the cultivation potential is high. There has been a consistent increase in the sweet cherry fruit cultivation and export over the years in Turkey. In 1980, 96.000 tons of sweet cherry fruit was produced without any exports. However, in subsequent years, the export volume increased significantly as 5445 tons (3.81\%) from a total of 143.000 tons of production in 1990; as 11.940 tons $(5.19 \%)$ from a total of 230.000 tons of production in 2000 , and 53.467 tons (10.81\%) from a total of 494.325 tons of production in 2013 (FAO, 2013).

The total area of sweet cherry orchards increased in proportion to exports. Sweet cherry fruit cultivation is carried out in an area of 847.461 decares in Turkey (TUIK, 2017). Sweet cherry fruit cultivation in Turkey starts in the shoreline of the western regions and extends to the Taurus mountains in the inner regions. Sweet cherry fruit cultivation season is increased due to elevation differences, optimal ecological advantages, and high duration of sunshine (Figure 1).

The long duration of sweet cherry fruit cultivation season is an advantage for Turkey. Table 1 shows the cultivation volumes by provinces. In Konya, located in the central Anatolia Region, the annual volume of sweet cherry fruit production is 55.426 tons and sweet cherry fruits in this province attain delayed ripening. In Izmir and Manisa, where early varieties are produced, the volume of production is nearly 100 thousand tons and represents $15.54 \%$ of total production (Table 1). Although the harvesting of early varieties commences in May in Turkey and is completed in August; June and July are the busiest months for harvesting cherries.

Copyright (C) 2018 Deniz Erogul

doi: $10.24294 /$ th.v1i2.623

EnPress Publisher LLC.This work is licensed under the Creative Commons Attribution-NonCommercial 4.0 International License (CC BY-NC 4.0). http://creativecommons.org/licenses/ by/4.0/ 


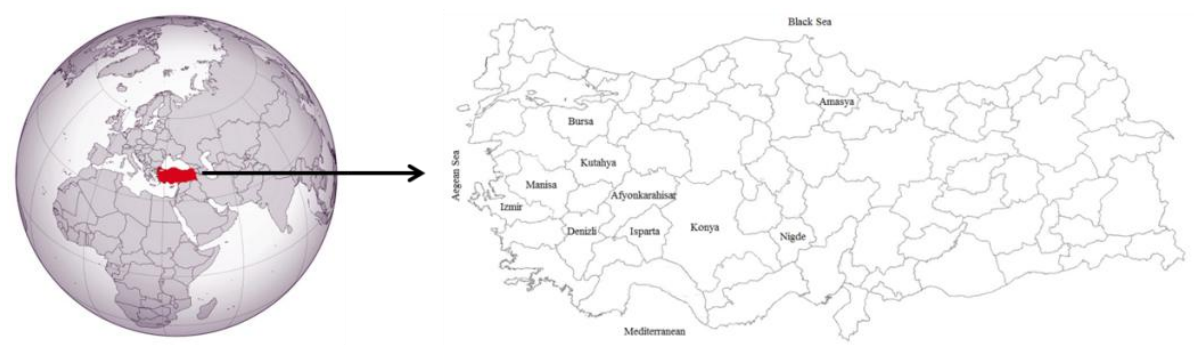

Figure 1; Cultivation Volume by provinces.

\begin{tabular}{|l|l|l|l|}
\hline Provinces & Production (ton) & Provinces & Production (ton) \\
\hline Isparta & 55657 & Kutahya & 35152 \\
\hline Konya & 55426 & Bursa & 32468 \\
\hline Manisa & 46648 & Amasya & 25008 \\
\hline Izmir & 46574 & Nigde & 23386 \\
\hline Afyonkarahisar & 40387 & Denizli & 22695 \\
\hline
\end{tabular}

Source: http://www.tuik.gov.tr Access Date: 01.03.2018

Table 1. Cultivation volume by provinces (TUIK, 2017)

\section{Sweet cherry orchard management}

The variety, '0900 Ziraat' is a unique one exported by Turkey and known all over the world as the Turkish sweet cherry and is a profitable investment opportunity because of its price and export potential. The variety, ' 0900 Ziraat,' is $26 \mathrm{~mm}$ and greater in size, is heart-shaped with dark red skin, and has a thin, long stalk. The pinkish red fruit flesh is hard, crunchy and juicy and contributes to fruit quality. The fruit pit adhesion is very low and resistant to cracking and is suitable for long transport distances. The most important feature of '0900 Ziraat' is its unique aroma, which imparts a unique characteristic to this variety. It is compulsory to plan the pollinizers for ' 0900 Ziraat' for its cultivation. The pollinizers used are usually Starks Gold, Lambert, Vista, Merton Late, Bigerreau Gaucher, Regina, Kordia, Noble and Jubilee varieties.

In sweet cherry orchards, the conventional seedling rootstocks are used as sweet cherry fruit rootstock. Mazzard rootstock is used by $40 \%$, Mahaleb rootstock is used by $29 \%$ and mostly, Gisela 5 and Gisela 6 are used as clonal rootstocks (Demirsoy et al., 2017). In addition to Gisela 5 and Gisela 6, the sweet cherry orchards are created using Colt, MaxMa14, MaxMa60, Cap6P, Weirot, SL64 rootstocks. Mazzard and Mahaleb rootstocks as conventional seedling rootstocks, which require 7-8 years to produce their first crop and full yield will be attained between 3 and 4 years in orchards created with clonal rootstocks. Cultivation is easier and efficient when it is made with dwarf and semi-dwarf clone rootstocks for maintaining the cultures. Therefore, cultivation with clonal rootstocks is preferred in new orchards; and conventional rootstocks are replaced with clonal rootstocks.

Pruning is performed with Goble and modified leader system; however, the training methods vary as cultivation with seedling rootstocks is widespread. Different training systems are introduced as clonal rootstocks are used in the new orchards.

Hypermarket and supermarket chains that market fruits in Europe deem importance to Global GAP that is based on "good agricultural practices" and strive to minimize the factors that harm human health with various protocols. Global GAP practices are also used for Turkish sweet cherry fruits, which are cultivated and delivered to consumers with due consideration of human health.

\section{Postharvest factors of sweet cherry and sweet cherry exportation}

Preharvest and postharvest factors of sweet cherry handling are important to sweet cherry quality and are interrelated. In addition to its long-established leading position in sweet cherry fruit production in the world, Turkey is a top supplier of sweet cherry fruit. External demand is the key factor for increasing the production. Factors such as packaging techniques, techniques for increasing the shelf life, price, avoiding adverse effects of agricultural chemicals 
on human health and quality can be listed as factors that would create a demand, which would eventually increase the export volume. Turkish sweet cherry fruits meet these criteria.

Sweet cherry fruits are extremely sensitive to pathological and physiological disorders and mechanical damages. Characteristics such as weight, hardness, colour, loss of aroma and acidity from the fruits, fruit decay, browning of stems, yellowing, drying, and mechanical damage to the crust and pitting limit the post-harvest life of the fruit. Therefore, it is necessary to perform the right applications from the harvest to the consumption. Pre-cooling process is applied to harvested sweet cherry fruits during the full ripening period immediately after harvesting or during the transportation to the facility. In Turkey, the pre-cooling process is carried out using water, which decreases the fruit seed temperature to $2-3^{\circ} \mathrm{C}$. Subsequently, sweet cherry fruits are kept for $1-2$ days at $1-2^{\circ} \mathrm{C}$ under cold storage conditions; and stalk separation, classification, and packaging procedures are carried out in the processing-packaging line. Modified Atmosphere Packaging (MAP) technology is used to maintain quality during storage and transportation of sweet cherry fruits. The sweet cherry fruits are processed in the packaging houses without breaking the cold chain; and are put into modified atmospheric packages; and then, their packaging is closed. These sweet cherry fruits are kept in cold room for a short period (1-2 days) and then transported by refrigerated vehicles. Although not common, late-harvest sweet cherry fruits are stored at $0^{\circ} \mathrm{C}$ for $2-4$ weeks under $90-95 \%$ relative humidity conditions.

\section{Sweet cherry exportation}

Turkey produces numerous local and foreign sweet cherry fruit varieties. The variety, '0900 Ziraat,' also known as "Turkish sweet cherry fruit," is the top variety for exports. The export volume for this variety represents $90 \%$ of the total exports. Turkey ranks $3^{\text {rd }}$ after the USA and Spain in global sweet cherry exports (FAO, 2013). Although Turkey is the leader among sweet cherry producing countries in the world, it ranks fourth in sweet cherry fruit exports because of the limited production of export quality sweet cherry fruits. In 2016, world sweet cherry export was 570.548 ton. Sweet cherry export ratio of Turkey represent $7.6 \%$ of the world. Top three sweet cherry exporters of the world are Chile, USA and Hong Kong-China with the ratios of 33.16\%, 19\% 14.5\% respectively (trademap, 2016). This high volume of exports in Chile can be attributed to the lack of other sweet cherry fruit exporters in the Southern Hemisphere. Chile does not have any competitors as harvesting is done in a different season in top cherry producing countries; and thus, the export volume increases.

European countries are the principal export markets for the Turkish sweet cherry fruit. Germany is the biggest export market as indicated by an export volume of 22.964 tons in 2017. The Russian Federation (14.376 t), Iraq (9.479 t), the Netherlands (2.558 t), Sweden (1.788 t), Austria (1.756 t), Norway (1.520 t), Italy (1.303 t), Denmark (885 t) import sweet cherry fruit from Turkey. In 2017, Turkey exported 439 tons of sweet cherry fruit to Hong Kong and China (trademap.org, 2017).

Quality is of prime importance as it is mandatory for export; thus, investing in modern irrigation systems such as drip irrigation and certified cultivation are within the scope of good agricultural practices. A survey among exporters showed that companies prefer overland transportation for exports by $97.59 \%$ and the most attractive market is the Russian Federation (Oz Cercinli and Bal, 2016).

\section{Conclusion}

Sweet cherry fruit is an important export product of Turkey. Therefore, quality is of utmost importance. Modern irrigation techniques are used, and certified cultivation is carried out within the scope of good agricultural practices. The geographical position and climate of Turkey allow continued sweet cherry fruit cultivation from early to a late period; and fresh product is cultivated for approximately 100 days. Furthermore, Turkey has an important advantage because of cultivation made with Turkish sweet cherry '0900 Ziraat'. The objective is to reflect the leadership in production in exports by taking the advantage of ecological richness in increased sweet cherry fruit cultivation areas.

\section{References}

1. Anonymous, 2017. http://www.tuik.gov.tr Access Time: 01.03.2018 
2. Anonymous, 2013 and 2017. Food and Agricultural Organization. http://www.fao.org, Access Time: 15.02 .2018

3. Anonymous, 2016 and 2017.Trade map.org, 2017 Access Time: 01.03.2018

4. Demirsoy, H., Demirsoy, L., Macit, I., Akçay, M.E., Bas, M., Demirtas, I., Sarısu, C., Taner, Y., Kuden, A. Sweet Cherry growing in Turkey-a brief overview. Acta Hortic. VII. International Cherry Symposium, 2017; 111-116. ActaHortic.2017.1161.19

5. Oz Cercinli, F., Bal, T. The Analysis of Cherry Export in terms of Cherry Exporter Perspective in Isparta Province. Journal of Agricultural Faculty of Mustafa Kemal University, 2016; 21(1):71-82

6. Anonymous, 2017. http://www.tuik.gov.tr Access Time: 01.03.2018

7. Anonymous, 2013 and 2017. Food and Agricultural Organization. http://www.fao.org, Access Time: 15.02.2018

8. Anonymous, 2016 and 2017.Trade map.org, 2017 Access Time: 01.03.2018

9. Demirsoy, H., Demirsoy, L., Macit, I., Akçay, M.E., Bas, M., Demirtas, I., Sarısu, C., Taner, Y., Kuden, A. Sweet Cherry growing in Turkey-a brief overview. Acta Hortic. VII. International Cherry Symposium, 2017; 111-116. ActaHortic.2017.1161.19

10. Oz Cercinli, F., Bal, T. The Analysis of Cherry Export in terms of Cherry Exporter Perspective in Isparta Province. Journal of Agricultural Faculty of Mustafa Kemal University, 2016; 21(1):71-82 